ISSN 1991- 8690

website:http:// jsci.utq.edu.iq
الترقيم الدولي 8690 - 1991

Email: utjsci@utq.edu.iq

\title{
Chemical analysis and antimicrobial activity of Cumin seeds extracted oil against some bacterial and fungal isolates
}

\author{
Rafeef Amer Abdul Jabbar \\ College of pharmacy - University of Basrah - Basrah -IRAQ
}

\section{Abstract}

Cuminum cyminum seeds oil was extracted by using Soxhelt extraction ,the chemical analysis is carried out by means of GC-MS ,1H-indene derivatives (59.77\%) and Cuminic aldehyde(13.77\%) are respectively the major compound in the extracted oil . The Cumin oil exhibits a strong antibacterial activity against four clinical bacterial isolates (Escherichia coli, Staphylococcus aureus, Klebsiella sp. and Pseudomonas aeruginosa) and strong to moderate antifungal activity against three fungal isolates (Aspergillus flavus ,Candida albicans and Cryptococcus sp.). The minimum inhibitory concentration (MIC) of the Cumin extracted oil was applied against the clinical isolates of bacteria and E.coli was the most sensitive isolate, with the lowest MIC value.

Keywords: Cuminum cyminum; Cumin oil; Antibacterial, Antifungal activity

$$
\begin{aligned}
& \text { التحليل الكيميائي و الفعالية المضادة للميكروبات لزيت بذور الكمون المستخلص } \\
& \text { رفيف عامر عبد الجبار } \\
& \text { كلية الصيدلة - جامعة البصرة - البصرة - العراق }
\end{aligned}
$$

تم استخلاص زيت بذور الكمون Cumin (Cuminum cyminum)بأستخدام جهاز الاستخلاص السوكسليه Soxhelt . وقد تم التحليل الكيميائي للزيت المستخلص بأستخدام كروماتوجرافيا الغاز-طيف الكتلة

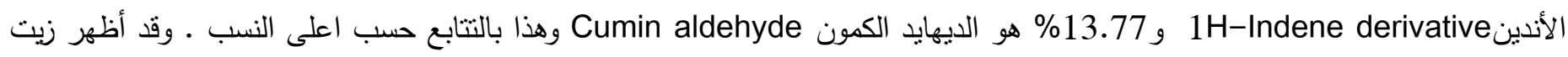
Escherichia coli ,Staphylococcus) Klebsiella sp. الكمون المستخلص فعالية بيولوجية عالية في تثبيط اربع عزلات جرثومية سريرية Candida Aspergillus flavus (Pseudomonas aeruginosag, aureus (Cryptococcus sp. galbicans , جرثومة E. coli هي اكثر الانواع الجرثومية تحسساً لزيت الكمون حتى مع التراكيز الواطئة منه. 


\section{Introduction}

Medicinal plants have always been considered a healthy source of life for all people [1]. Nowadays people are being bombarded with a thousand of unhealthy products, and also the problem of antibiotic resistance that is a worldwide public health problem that continues to grow [2]. All that makes the use of medicinal plants is the best choice for the treatment of different diseases and infections [1]. One of these medicinal plants is Cumin (Cuminum cyminum) its an herbaceous annual plant of the Umbellifera family and is used as a condiment and as an ingredient in many food industries [3,4]. From the most important medical uses of Cumin are to reduce inflammation increase ,urination , prevent gas and suppress muscle spasms and it is also used as an aid for ingestion , jaundice, diarrhea and flatulence [5]. Cumin cultivate in Western Asia, South Mediterranean and the main producer countries today are India, Iran and Indonesia [3].

Generally the medicinal importance and the spicy flavor of Cumin belong to the Cumin seeds [5]. Cumin seeds are oblong in shape longitudinally ridged and yellow-brown color [3]. Also Cumin seeds contain essential oil (up to 5\%) that imparts the generally the medicinal importance and the spicy flavor of Cumin belong to the Cumin seeds [5]. Cumin seeds are oblong in shape longitudinally ridged and yellow-brown color [3]. Also Cumin seeds contain essential oil (up to 5\%) that imparts the characteristic aroma to the seeds [4]. Essential oils extracted by hydro distillation from fruits of Cuminum cyminum the main components of Cuminum cyminum oil were $\mathrm{p}$ mentha-1, 4-dien-7-al, cumin aldehyde, Gamaterpinene, and $\alpha$-pinene [12], Cumin essential oil has a broad antibiotic spectrum against Grampositive and Gram- negative bacteria [15], and more research showed that Cuminum cyminum essential oil is active in general against all fungi [20] .

Cumin seeds are the most popular spice all over the world and they are very popular in western to the central Asia[6] they are found in a large amount in our Iraqi market and sold in a low price, the aim of this study is to analyse the chemical composition and testing the ability of Cumin oil from a seeds collected from Basra markets and extracted in our laboratories by soxhelt and Ether as a solvent, to detect its antibacterial action on the growth of clinical isolates of some bacterial and fungal isolates.

\section{Materials and methods}

\section{Materials}

Cuminium cyminum seeds were obtained from the local market of Basra city in Iraq. Four types of media were used [Nutrient agar, Nutrient broth, Sabouraud-Dextrose agar (Himedia company) and Muller-Hinton agar (CDH) .Four clinical isolates of bacteria (Escherichia coli, Staphylococcus aureus, Klebsiella sp. and Pseudomonas aeruginosa) and three fungal isolates (Aspergillus flavus, Candida albicans and Cryptococcus sp.) are used, all of these isolates obtained from Pharmacology department in the college of pharmacy .

\section{Methods}

\section{Oil extraction and chemical analysis}

Cumin seeds oil was extracted using Soxhelt extraction[4], which carried out in standard apparatus for 12 hours using (20)gm of Cumin seeds with (200)ml of Diethyl ether as a solvent. Then the extracted oil was collected in a dark glass container and stored in a freezer until use.

The chemical analysis for the extracted oil was examined using GC-MS analysis which is performed by using Shimadzu GC-2010 system coupled with a Shimadzu GCMS-QP2010 Ultra network mass selective detector and equipped with DB-1MS capillary fused silica column $(30 \mathrm{~m}$

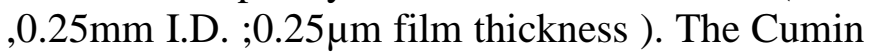
oil solution $(1 \mu)$ in Diethyl ether (HPLC grade) was injected and analyzed with the column held initially at $40 \mathrm{C}^{\circ}$ for $5 \mathrm{~min}$ and then increased to $250 \mathrm{C}^{\circ}$ with a $4 \mathrm{C}^{\circ} / \mathrm{min}$ heating ramp and subsequently kept at $250 \mathrm{C}^{\circ}$ for $1 \mathrm{~min}$. other 
operating conditions were as follows: carrier gas, $\mathrm{He}(99.999 \%)$; with a flow rate of $1.82 \mathrm{ml} / \mathrm{min}$ : injector temperature, $250 \mathrm{C}^{\circ}$; split ratio,1:50. Mass spectra were taken at 70ev. Mass range was from $\mathrm{m} / \mathrm{z}$ 35-50 amu. the relative percentage amount of the separated compounds were calculated from total ion chromatograms by a computerized tegrator literature data and MS data by MS data obtained from NIST 08 library [7].

\section{Antimicrobial activity}

The antibacterial activity of the extracted oil was assayed by using four clinical bacterial isolates $[E$. coli isolated from stool specimen, Klebsiella sp., Psudomonas aeruginosa and Staphylococcus aureus all isolated from blood specimen ] with a microbial concentration $10^{6}$ $\mathrm{CFU} / \mathrm{ml}$ and by Well-diffusion method on MullerHinton agar [8,9] and the inhibition zone was measured in millimeter $(\mathrm{mm})$. Four Petri dishes were used as an experimental unit and the trial was repeated twice. Cultures were incubate at $37 \mathrm{C}^{\circ}$ for 24 hours. Similarly, the antifungal activity of the extracted oil was tested against three fungal isolates [Aspergillus flavus, Candida albicans, Cryptococcus sp.] and by using Sabouraud Dextrose agar medium, three Petri dishes were used as an experimental unit and the trial is repeated twice. The fungal cultures were incubate at $27 \mathrm{C}^{\circ}$ for three days [11].

\section{Minimal Inhibitory Concentration (MIC)}

The minimal inhibitory concentration (MIC) of the Cumin extracted oil against the four clinical isolates of bacteria is carried out using Well diffusion method[10,25], different concentration of the extracted oil (0.95, 0.85, 0.75, 0.65, 0.6, 0.55 , $0.45,0.35,0.1,0.04 \mathrm{ml} / \mathrm{ml})$ were prepared using Diethyl ether as diluent [15]. The MIC of the Cumin oil for each bacterial isolates was regarding as the lowest concentration that inhibited visible growth of the bacterial isolates on the agar plate after 24 hours incubation at $37 \mathrm{C}^{\circ}$. And the Diethyl ether used in this test as a negative control [10].

\section{Results and Discussion}

Result of GC-MS analysis of Cuminum cyminum seed extracted oil in table(1) and figure (1)show the chemical composition of the extracted oil, in which the main components of the extracted oil were 1 Hindene derivatives $(59.77 \%)$, Cuminic aldehyde (13.77\%) and Cuminol (3.08\%). The antibacterial activity of the extracted oil in table(2) and figures(2) show a good antibacterial activity when compared with the standard antibiotic with a nearly concentration [24], that belongs to the chemical composition of Cumin extracted oil which contain Cuminic aldehyde ,P-menth-2-en-7ol ,Gamma-Terpine , $\beta$-Pinene and else all of these compound despite of their little concentration but they are contribute in the antibacterial activity because they are known bactericidal compounds[12,13], especially the Cumin aldehyde which has a high concentration $(13.77 \%)$ in the extracted oil and this compound exhibited a considerable inhibitory effect against different Gram positive and Gram-negative bacteria isolates $[14,15,16,17]$. Also it was supported by (MIC) results of the extracted oil against the bacterial isolates table (3).

Isolation and extraction of each compounds and testing its antimicrobial activity are processes required long time that's it can be done as a further step for this study, there are no reports about the antimicrobial activity of $1 \mathrm{H}$-indene derivative that is found in the extracted Cumin oil, but some of the $1 \mathrm{H}$-indene derivatives have antimicrobial activity and use as antibiotic intermediate [22]. The results of MIC in table (3) show that the Cumin extracted oil is more active against $E$. coli $(4 \% \mathrm{ml} / \mathrm{ml})$ than the other used clinical isolates, in this action it resembles the antimicrobial activity of the Cumin essential oil against $E$. coli which records in some research were lowest $\mathrm{MBC}$ value $(1 \mu \mathrm{l} / \mathrm{ml})$ [23]. That's because of the some similarity between the research extracted oil and the Cumin essential oil in the chemical structure which have nearly the same bactericidal compounds [12]. Also the present study which reported antibacterial potential of a different types of spices including Cumin 
found a potent antibacterial potential against $E$. coli and Bacillus subtilis [13].The mechanism of action of Cumin oil in some bacterial cells can be represented by cell elongation, repression of capsule expression in some bacteria and inhibition of Urease activity $[18,19]$. The high MIC value against the other clinical isolates of bacteria can attributed to the fact that some of Cumin extracted oil compounds especially the aromatics that most of which have an antimicrobial activity[18] may lost or volatile after a period of time even when stored in the freezer by repeated use of oil and put its container for hours in room temperature during the tests period, that explain the high MIC value because the accounting of MIC value is the latest test in this study and carried out after a few months of Cumin oil extraction while detecting of antimicrobial activity is carried out under the same conditions of MIC test but shortly after oil extraction. Susceptibility of E. coli in the study, suggests that other compounds of the oils have exerted a antimicrobial effect [23].

The Cumin extracted oil has antifungal activity against the fungal isolates table(2) and figure(3) that also belongs to the presence of some compounds in its chemical composition like Cumin aldehyde , P-cymen and Pinene [12,20]because these compounds and other phenolic compounds of Cumin oil are able to inhibit some important fungal enzymes like Pectinase which is used by some fungi to hydrolyze the fruit cell wall and invade the host cell and form fruit decay[21]and some research found that the Cumin oil blocked the growth of fungi and can completely stop fungal growth in modest concentration [5], the Cumin essential oil has an antifungal activity against Aspergillus sp. and Candida albicans [12,20] and that resembles the research Cumin extracted oil, that mean the both oils have the same action because they have the same active compounds.

\section{Conclusion}

In this study we observed that the Cumin (Cuminum cyminum) plant is used from most of the people as a kind of spicy in their food and its seeds are present in our markets and sold in a low price and the seeds extracted oil have an antibacterial and antifungal activity all that can enable us to use this extracted oil in the treatment of human, animals and plant microbial disease. And also about $(59.77 \%)$ of Cumin extracted oil is $1 \mathrm{H}-$ indene derivative and because Cumin extracted oil have an antibacterial and antifungal activity there for this compound may have an antimicrobial activity that lead us to further extraction for this compound and testing its antibacterial and antifungal activity. Finally the Cumin extracted oil must be kept in a tightly closed container in the freezer and avoid put it for a long time in a room temperature to keep its volatile compounds. 


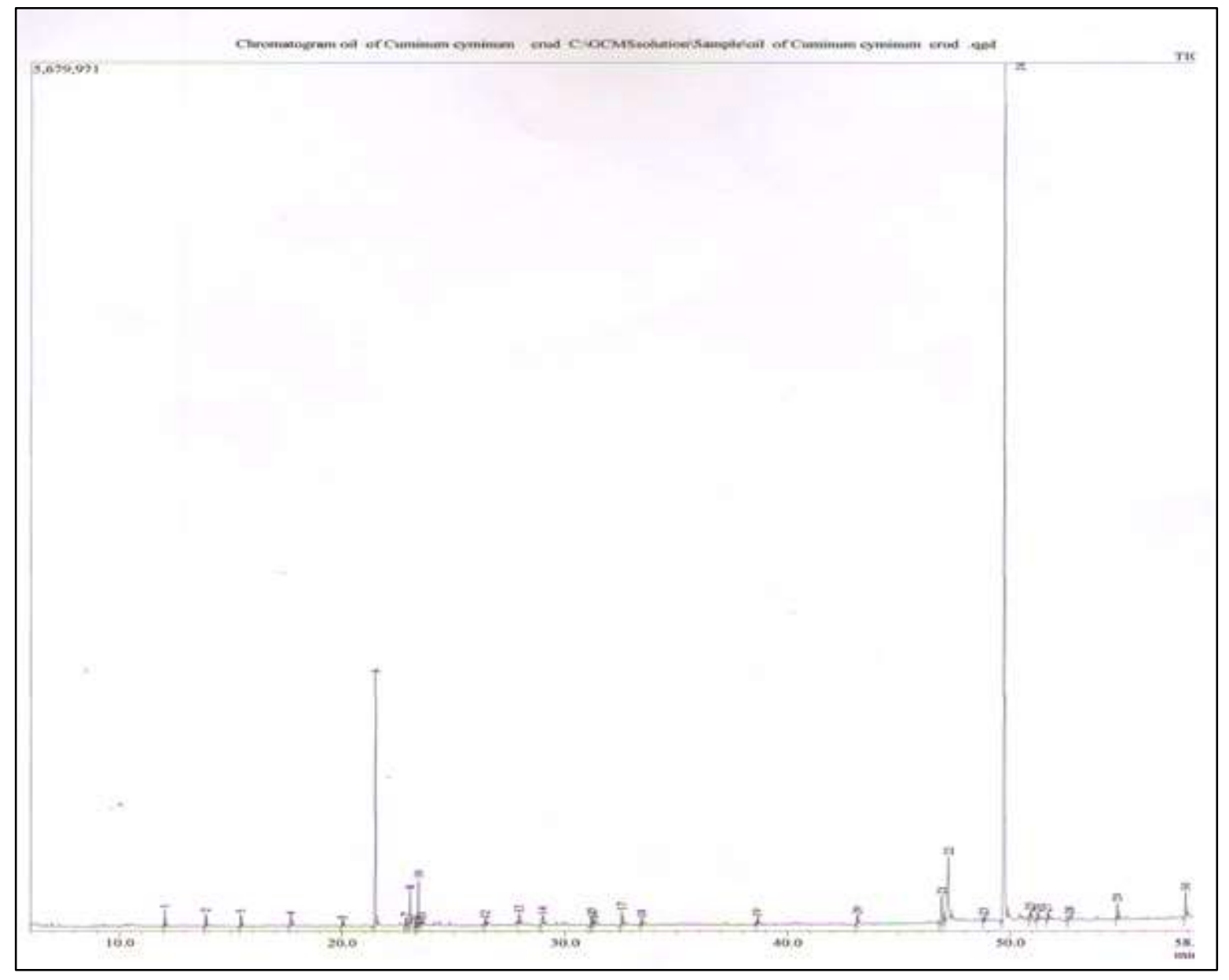

Fig-1- GC-MS analysis of Cuminum cyminum extracted oil 
Table-1-The chemical composition of Cuminum cyminum extracted oil.

\begin{tabular}{|l|l|l|l|}
\hline NO & \multicolumn{1}{|c|}{ Compounds } & $\underline{\mathbf{R T}}$ & $\mathbf{\%}$ \\
1 & Beta-Pinene & 12.031 & 0.85 \\
2 & Beta-Cymene & 13.885 & 0.67 \\
3 & Gamma-Terpine & 15.455 & 0.64 \\
4 & Undecane & 17.687 & 0.69 \\
5 & Phellandral & 20.021 & 0.32 \\
6 & Cumic aldehyde & 21.492 & 13.77 \\
7 & P-Menth-2-en-7-ol,trans. & 22.878 & 0.44 \\
8 & 2-Caren-10-al & 23.058 & 1.87 \\
9 & 1-Phenyl propane-1,3-diol & 23.318 & 0.31 \\
10 & Cuminol & 23.430 & 2.61 \\
11 & 2-Methyl-1,3-cyclopentadione & 23.580 & 0.23 \\
12 & Trifluoroacetyl- camphenilol & 26.447 & 0.31 \\
13 & Cuminic acid & 27.954 & 0.66 \\
14 & Spiro[4,4]non-3-en-2-one,4 methyl-3-(1H-tetrazol-5-yl)oxa & 29.011 & 0.77 \\
15 & P-isopropylphenetole & 31.213 & 0.52 \\
16 & Admantane-1-carbohydrazide,N2-(4-methylbenzylideno) & 31.306 & 0.40 \\
17 & 14-Methyl-8-Hexadecenal & 32.566 & 0.85 \\
18 & Carotol & 33.458 & 0.35 \\
19 & 5H-3,5a-Epoxynaphth[2,1-c]oxepin. & 38.651 & 0.35 \\
20 & 1-(+)-Ascorbic acid 2,6-dihexadecanoate & 43.144 & 0.54 \\
21 & Linoleic acid & 46.936 & 2.19 \\
22 & 6-Octadecenoic acid & 47.220 & 6.26 \\
23 & 2-(1,3-Benzodioxol-5-yl)-1-(5-ethyl-2-hydroxy-4-methox) & 48.828 & 0.23 \\
24 & 1H-indene derivative* & 49.731 & 59.77 \\
25 & 1,3-Cyclohexadiene,1,2,3,4,5,6-hexamethyl & 50.907 & 0.44 \\
26 & Eicosane & 51.222 & 0.51 \\
27 & Oxalic acid monoamide, N-(4-ethylphenyl)-propyl ester & 51.681 & 0.38 \\
28 & 2,3-Dihydroxypropyl elaidate & 52.672 & 0.37 \\
29 & 3-Methyl-2-butenoic acid, cyclobutyl ester & 54.810 & 1.01 \\
30 & 2-Butenoic acid,2-methyl-,dodecahydro-8-hydroxy-8a- & 57.870 & 1.69 \\
& methyl-3,5-bis(methylene). & & \\
\hline
\end{tabular}

RT: retention time , \%:Area\% ,*1H-Indene,2,3,3a,4,7,7a-hexahydro-2,2,4,4,7,7-hexamethyl.

Table-2- Antibacterial and antifungal activity of Cuminum cyminum extracted oil against the clinical isolates of bacteria and fungi.

\begin{tabular}{|l|c|}
\hline \multicolumn{1}{|c|}{ Clinical isolates of bacteria } & Inhibition zones $\mathbf{( m m )}$ \\
\hline \multicolumn{1}{|c|}{ Staph. aureus } & 37 \\
\hline E.coli & 40 \\
\hline P.aeruginosa & 40 \\
\hline Klebsiella sp. & 45 \\
\hline Fungal isolates & 19 \\
\hline Aspergillus flavus & 20 \\
\hline Candida albicans & 22 \\
\hline Cryptococcus sp. & \\
\hline
\end{tabular}



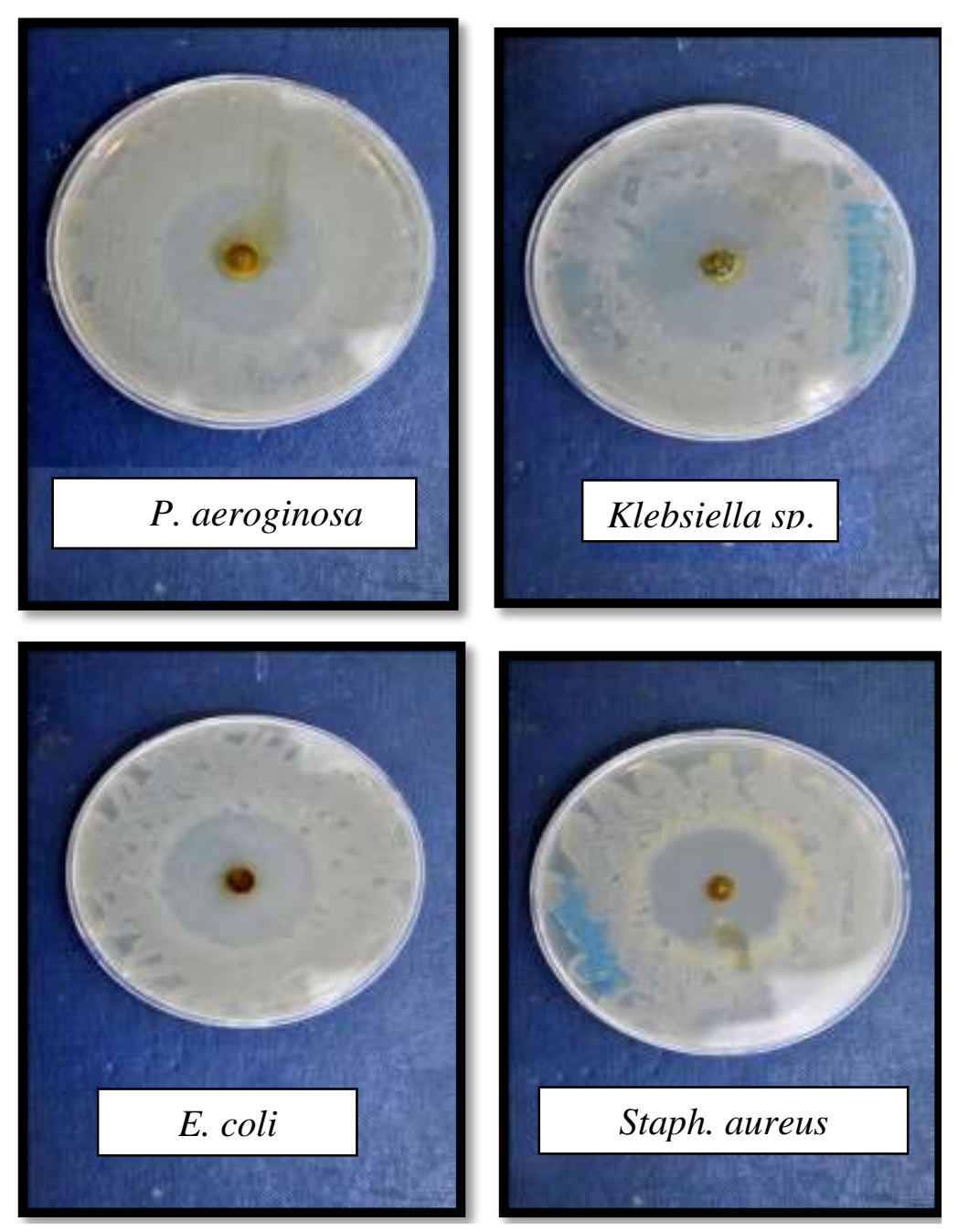

Fig-2- Antibacterial activity of Cuminum cyminum extracted oil.
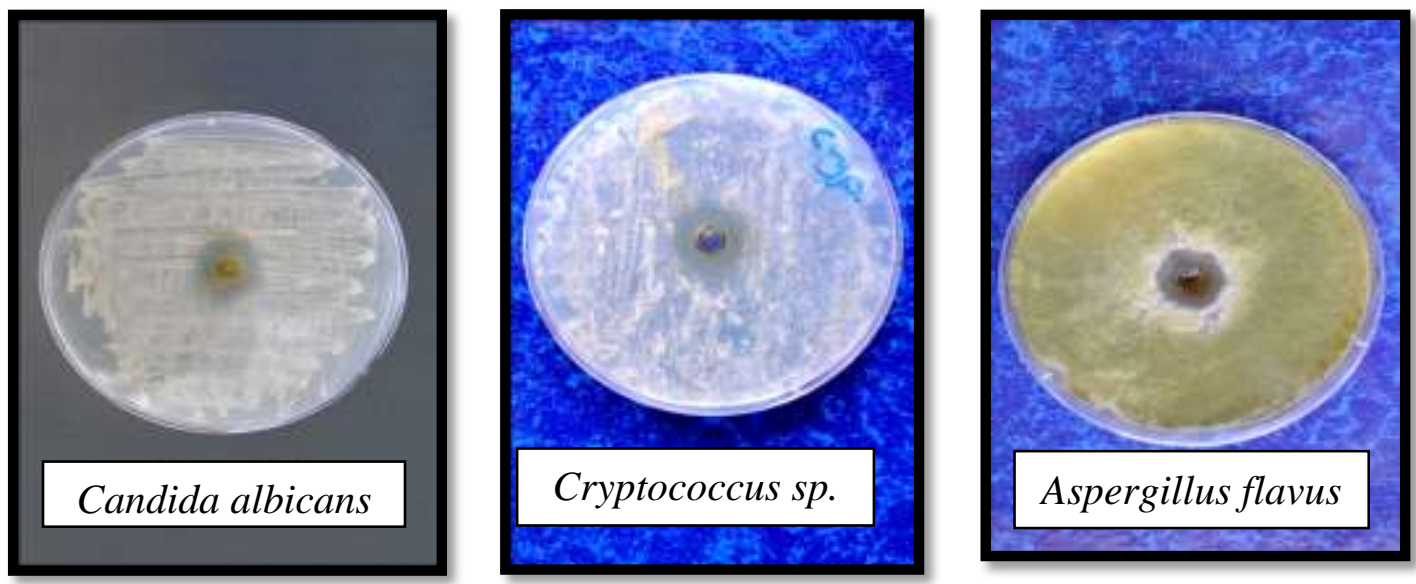

Fig-3-Antifungal activity of Cuminum cyminum extracted oil. 
Table-3- Minimal inhibitory concentration of Cuminum cyminum extracted oil against the clinical isolates of bacteria.

\begin{tabular}{|c|c|}
\hline Clinical isolates of bacteria & MIC $(\mathbf{m l} / \mathbf{m l})$ \\
\hline Staph. aureus & 0.6 \\
\hline E. coli & 0.04 \\
\hline P. aeruginosa & 0.65 \\
\hline Klebsiella sp. & 0.35 \\
\hline
\end{tabular}

\section{References}

1-P.P. Joy ,J. Thomas ,S. Mathew ,B. P. Skaria "Medicinal plants" Kerala Agricultural university, (1998).

2-F. C. Tenover "Mechanisms of antimicrobial resistance in bacteria" the American journal of medicine (2006) vol.119 (6A) S3-S10.

3-A. Bahraminejad, G. Mohammed-Nejad, M. Abdulkhadir "Genetic diversity evaluation of Cumin (Cumin Cyminum L.) based on phenotypic characteristics" Australian journal of corp sciece (2010), 5(3):304-310.

4-M. H. Eikani, F. Golmohammad, M. Mirza and S. Rowshanzamir "Extraction of volatile oil from Cumin (Cuminum cyminum L.)with super heated water" Journal of food process engineering(2007), 30,255-266.

5-Igram, Cass "Cumin oil as a plant and spice" self published, (1997), Buffalo grove, Illinas.

6-M. Douglas ,J.tleyes and B. Smallfied "Herbs ,spices and essential oils post-harvested operation in developing countries" (2005) (CUNIDO and FAO.

7-P. Sandra ,C. Bicchi "Capillary gas chromatograph in essential oil analysis" Alfred Huthig-Verlag, (1987) :Heidelberg.

8-C. Delahaye ,L. Rafinford ,A. Nicholson ,S. Mitchell J. Lindo and M. Ahmad "Antibacterial and Antifungal analysis of crude extracts from the leaves of Callistemon viminalis " Medical and Biological science (2009), vol.3 ,issue1.

9-C. Valgas ,S. Machado do Souza ,E. F. Smania and A. Smania Jr"Screening methods to determine antibacterial activity of natural products" Brazilian Journal of microbiology 9(2007) 38:369-380.

10- S. S. Gautam, Navneet ,S. Kumar and Prabhat "Screening of antibacterial activity of Nepeta ciliaris Benth. against respiratory tract pathogens" Kathmandu university Journal of science(2012), vol.8, no.1, pp.8590.

11-T. M. Muhsin, A. A. Al-Duboon and K.T. Khalaf "Bioactive Compounds from a Polypore Fungus Ganoderma applanatum (Per s. ex Wallr.) Pat."Jordan Journal of Biological Sciences,(2011), Vol.4, No.4,P(205-212) .

12-N. S. Iacobellis, P. L. Cantore, F. Capasso and F. Senatore "Antibacterial activity of Cuminum cyminum and Carum carv. L. essential oils" J. Agric. Food chem. (2005),53 ,57-61.

13-N. M. Chudhry and P. Tariq "in vitro antibacterial activity of Kabnji, Cumin and Poppy seed" pak .J.Bot., (2008) ,40(1):461467. 
14-J. Wanner, S. Bail, L. Jirovetz, G.Buchbauer, E. Schmidt,V. Girova ,T. Atanasova AND A. Stoyanova "Chemical composition and antimicrobial activity of Cumin oil(Cuminum cyminum , Apiaceae)" Nat. prod. Commun.( 2010) Sep;5(9):1355-8.

15-N. H. Jazani, M. Zartoshti and S. Shahabi "Antibacterial effect of Iranian Cuminum cyminum essential oil on burn isolation of Pseudomonas aeruginosa" International Journal of Pharmacology, (2008), Issu 187775 (C) 2008 Asian network for scientific information.

16-Elfahmi "Phytochemical and biosynthetic studies of lignans with focus on Indonesian Medicinal plants "Rijks University Groningen. (2006), ISBN: 90-902-0771-6.

17-H. Hajlaoui ,H. Mighri ,E. Noumi ,M. SnoussI ,R. KsourI and A. Bakhrouf "Chemical composition and biological activity of Tunisian Cuminum cyminum L. essential oil :a high effectiveness against Vibrio spp. Strain" Food chem. Toxicol. (2010) Aug-Sep , 48(8-9):2186-92 .

18-R. K. Johri "Cuminum cyminum and Carum carvi: An update" Pharmacogn. Rev. (2011) Jan-Jun; 5(9):63-72.

19-S. Derakhshan, M. Sattari and M. Bigdeli "Effect of Cumin (Cuminum cyminum) seed essential oil on biofilm formation and Plasmid integrity of Klebsilla pneumonia" Pharmacognosy magazine (2010) vol:6 ,Issu:21, page 57-61.

20- C. Romagnoli, E. Anderotti, S. Maietti, R. Mahenddra andD. Mares "Antifungal activity of essential oil from fruits of India Cuminum cyminum" Pharm. Biol. (2010) Jul; 48(7):834-8.

21-A. Marjanlo A., Y. Mostofi ,Sh. Shoeibi and M. Fattahi "Effect of Cumin essential oil on post harvested Decay and some quality factors of Strawberry" Journal of medicinal plants, (2009): Volume 8, No. 31.

22- W. Li, M. Lie, D. Fei, K. Gao "Eremophilanetype sesquiterpene derivatives from Ligularia hodgsonii", Plant medical,(2009), (impact factor2.04) ; DOI:10.1055/s-0029-1185359.

23- L. Gachkar , D. Yadegari , M. B. Rezaei , M.Taghadeh , S. A. Astaneh , I. Rasooli "Chemical and biological characteristics of Cuminum cyminum and Rosmarinus officinalis essential oil ",Food chemistry ,(2007) :Vol 102 ,Issu 3,pages 898-904.

24-G. Singh, I. P. kapoor, S. K. Pandey, U. K. Singh and R. K. Singh "Studies on essential oils :part 10; Antibacterial activity of volatile oils of some spices" Phytother. Res. (2002), 16(7):680-682.

25-S. G. Jonathan and I. O. Fasidi "Antimicrobial activity of two Nigerian edible macro-fungi Lycoperdon pusilum (bat. ex) and Lycoperdon giganteum (pers.)" African Journal of biomedical research (2003), Vol.6 ,No.2 ,pp:85-90. 